\title{
Influence of Tillage Methods and Plant Protection Agents on the Ecological Parameters of Soil Cover and Barley Yield
}

\author{
Aizhan A. Sardar ${ }^{1}$, \\ postdoctoral student, e-mail: s_aizhan.888@mail.ru; \\ Zhanar S. Tileubaeva ${ }^{2}$, \\ Ph.D.(Biol.) \\ ${ }^{1}$ National Agrarian University, Almaty, Kazakhstan; \\ ${ }^{2}$ Kazakh National Women's Teacher Training University, Almaty, Kazakhstan
}

\begin{abstract}
Excessive and unbalanced use of the pesticides that is necessary to protect agrophytocenoses against pests leads to environmental pollution. Harmful pesticides tend to enter the natural cycles of substances. Therefore, they are quick to disappear or be destructed by biological agents. There are also "nondestructive" pesticides, which do not enter the natural cycles; neither they are accumulated in food chains and in biotopes. These substances have become an object of research in the field of environmental safety.
\end{abstract}

Keywords: soil erosion, soil tillage, pesticides, barley, weed plants, efficiency of plant protection agents, ecological compatibility.

IFor citation: Sardar A.A., Tileubaeva Zh.S. Influence of tillage methods and plant protection agents on the ecological parameters of soil cover and barley yield. Sel'skokhozyaystvennye mashiny i tekhnologii. 2019. Vol. 13. N3. 8-10 (In English). DOI 10.22314/2073-7599-2019-13-3-8-10.

\section{Влияние приемов обработки почвы и средств защиты растений на экологическое состояние почвенного покрова и урожайность ячменя}

\author{
Айжан Анарбеккызы Сардар ${ }^{1}$, \\ докторант, e-mail: s_aizhan.888@mail.ru;
}

\author{
Жанар Слямхановна Тилеубаева², \\ кандидат биологических наук
}

${ }^{1}$ Казахский национальный аграрный университет, Алматы, Казахстан;
${ }^{2}$ Казахский национальный женский педагогический университет, Алматы, Казахстан

Реферат. Чрезмерное и несбалансированное использование пестицидов, необходимых для защиты агрофитоценозов от вредителей, приводит к загрязнению окружающей среды. Ядовитые пестициды вступают в естественные циклы круговорота веществ. Они быстро исчезают или подвергаются уничтожению биологическими агентами. Есть также «невредные» пестициды, которые не вступают в естественные циклы круговорота веществ и не накапливаются в пищевых цепочках и в биотопах. Эти вещества стали предметом исследования в области экологической безопасности.

Ключевые слова: эрозия почвы, обработка почвы, пестициды, ячмень, сорняки, эффективность средств защиты растений, экологичность.

$\mathrm{T}$ he problem of rational using farmlands has become increasingly important. Intensive farming with application of annual moldboard plowing as the main cultivation method without taking into account agro-ecological characteristics of a relief, leads to the degradation of a soil cover. Strengthening of erosive processes on these soils leads to impoverishment of organic matter, decreased soil fertility, and deterioration in a phytosanitary condition of crops.

An important factor in increasing the yield of grain crops is effective scientifically based tillage. Repeated tillage contribute to topsoil dispersion, soil structure disturabance, fast decomposition of organic matter, degradation and decrease of the soil fertility, the compaction of topsoil and plough-pan, erosive processes and significant increase in material inputs.
The conventional tillage technology is based on moldboard plowing and requires considerable power and labor expenses. It takes about $36-38 \%$ of fuel from the need for cultivation of any crop as a rule, plowing is not carried out at the optimum time, and in the most cases, it is necessary to carry out spring plowing, which significantly delays the sowing time.

At zero-tillage farming there is no turnover of layer, and the stubble remains of plants do not penetrate completely into the soil, they are only mixed up with it, thus forming the mulching layer. This organic matter is accumulated mainly in the upper part of the topsoil, where favorable conditions for the access of air, moisture and heat are created, which contribute to the rough microbiological processes in the soil. 
The problem of degradation of arable lands owing to appearance of erosive processes is particularly acute not only in Kazakhstan. Increase in population, intensive development of agricultural production result in increased anthropogenic effects. Intensive farming, leading to decrease in fertility of the soil, change of the natural soil cover, plowing of virgin lands of forest-steppe and steppe areas, deforestation, strengthen erosive processes even more. It leads to the reduction of arable land areas, their degradation and thus, reduced crop yields of a decreased quality.

One of the factors reducing the fertility of eroded soils is the impoverishment of organic matter leading to a decrease in biological activity. Due to the disturbance of normal microbiological processes, accumulation of mineral nutrients by plants, decomposition of plant residues, humus synthesis, etc. are weakened in these soils.

Another factor, significantly reducing the field crop yields is the contamination of crops by weeds. Weeds, owing to their biological features, negatively influence on the balance of nutrients, water-air, heat and light conditions; they fiercely compete with cultural plants for life factors, oppressing their growth, reducing the effectiveness of applied agricultural methods, mineral and organic fertilizers, and, as a result, the crop yield decreases. The use of soil-protective tillage technologies without applying highly effective herbicides leads to more intensive contamination of field crops with perennial weeds, and unsystematic use of pesticides leads to environmental pollution and deterioration of the phytosanitary condition of crops.

According to V.A. Zakharenko (2004), potential yield losses from pests on average account for 50.1 million tons of grain on agricultural enterprises, and on personal farms48.7 million tons. Potential yield losses for different crops from weeds account for 17.3-26.6\%; diseases of $8-24 \%$; and pests of $8.25-20 \%$.

Agricultural experience of many enterprises shows that up to $40 \%$ and more areas of grain crops are cultivated on adverse predecessors. According to generalized data, the yield of barley is reduced to $30 \%$ exactly due to phytosanitary reasons as crops are sown after bad predecessors. In modern agriculture the greatest opportunities to save energy resources are available on condition that fodder grass cultivation is organization more efficiently, which is one of the main links of agricultural biologization.

Therefore, now, when the range of safe chemical agents extends and their application grows, there is a need to develop new systems of crop protection combined with soil protection tillage systems, which would consider agro-ecological features of farm lands. This will allow reducing anthropogenic impacts, erosive losses, while improving the phytosanitary condition of crops and ensuring stable crop yields of high quality [1].

Broad use of pesticides in agricultural practice has led to the fact that all countries of the world face problems of the waste of pesticides. According to T. Bicki and A.Felsot, in the USA there are 14,000 agrochemical companies for storage, sale, mixing or use of pesticides. The similar enterprises are placed in many other countries as well. The condition of the soil polluted by pesticides because of floods, improper storage, inadequate disposal of washouts and containers and accumulation of the remains of chemical agents of crop protection is become a current problem not only in the USA, the countries of Europe, the CIS, but also in our Republic [2, 3].

Migration or transfer of elements and natural compounds is one of the geochemical regularities of the biosphere. Recently, the various xenobiotic substances, which are artificially put into the landscape are involved in this all-planetary process as well; it is also related to pesticides, products of their transformation and destruction. The process of migration is believed to determine the various consequences for the biosphere of biocides and other xenobiotics (landscape-regional, regional-basin and global after-effects). Migration can be characterized as a complex process of the redistribution of xenobiotics (and products of their transformation) in space and time. Pesticides can be transformed into various products in the process of such redistribution. Invariable initial compounds with products of its transformation are usually called pesticide residues. Processes of pesticide transformation in soils were considered in detail [3-5].

In laboratory researches of pesticide behavior in the environment, the following processes are considered separately: metabolism by microorganisms, movement in the soil, photodecomposition on the surface and in the vaporous state, evaporation from surfaces of plants or the soil, absorption by plants. But these processes can take place at the molecular level in the environment, so at each stage of the dispersion of pesticides, one or several processes can play a major role. At present, used various methods are used to study the accumulation, action and extent of pesticide decomposition in soils, and also their neutralizations by chemical, biological and other means. Soil pollution is controlled based on monitoring the threshold limit values (TLV) of harmful substances in the soil which are established approximately for 50 substances, mainly the toxic chemicals used for crop protection against pests and diseases.

So far as adverse influence of pollutants on the soil is shown through the trophic chain, in practice use is made of two indicators to assess the extent of soil pollution:

- threshold limit value in the soil (TLV), $\mathrm{mg} / \mathrm{kg}$;

- acceptable residual quantities (ARQ), $\mathrm{mg} / \mathrm{kg}$ of crop mass (Table) [6].

In Kazakhstan, the research in the field of the environmental and economic assessment of agricultural lands started from the 1990s and they are taking rather a new course. The situation is complicated by the absence or limitation of environmental monitoring data on land resourc- 


\begin{tabular}{|l|c|c|}
\hline \multicolumn{3}{|c|}{ ThRESHOLD LIMIT VALUES (TLV) OF HARMFUL SUBSTANCES IN THE SOIL } \\
\hline \multicolumn{1}{|c|}{ Pesticide } & $\begin{array}{c}\text { TLV, } \\
\mathbf{m g} / \mathbf{k g}\end{array}$ & $\begin{array}{c}\text { ARQ, } \\
\mathbf{m g} / \mathbf{k g}\end{array}$ \\
\hline Chlorophos (trichlorfon) & 0.5 & 1.0 \\
\hline Karbofos (malathion) & 2.0 & 1.0 \\
\hline Prometrin (prometrin) & 0.5 & 0.1 \\
\hline Polychlorocamphene (toxaphene) & 0.5 & 0.1 \\
\hline Ramrod (propachlor) & 0.3 & 0.2 \\
\hline
\end{tabular}

es. Therefore, the development and implementation of environmental and economic assessment did not reach the level of foreign countries with developed economies. Nevertheless, at present certain theoretical-methodical bases are formed and practical experience of carrying out environmental and economic assessment of agricultural lands located in different regions of the country with various natural-economic conditions is gained.

According to data of Committee of Statistics of the RK Ministry of Economics, in 2018, in Kazakhstan 15.135 million hectares were sown by grain crops that is $2 \%$ lower than the last season indicator. According to data, wheat crops were reduced almost by 570 thousand hectares (4$5 \%$ ). Also the acreages of rice, rye and buckwheat decreased to 102 thousand hectares $(-3 \%), 21.6$ thousand hectares $(-11 \%)$ and 99.2 thousand hectares $(-33 \%)$ respectively. Nevertheless, the acreages, recorded for this crop -2.5 million hectares, are sown with barley that is $22 \%$ higher than the last season indicator.

Diversification of the crop industry in specific climatic conditions of Kazakhstan showed high ecological and economic fitness of barley that allows to develop ecologically flexible, salt-, drought-resistant varieties of this crop. Barley continues to be the most economical and productive grain and fodder crop in Kazakhstan, and it has considerable specific weight in the grain crop structure $-26 \%$ [8].

In developing the integrated systems of protection against pests, one should constantly search for pesticides, which are low-toxic for the humans, and the dangers associated with their destruction and transformations in the environment, circulation as both initial combinations and metabolites should be avoided. It should be noted that development costs of highly effective and ecologically safe pesticides are very high, both in terms of economics, and research, however in case of positive result they pay off, taking into account social interests. Long corresponding researches, which will allow to rethink the strategy of their use, are necessary to clarify the process regularities of cleaning landscape and its separate elements from pesticide residues. Development of methods to reduce the mobility of pesticides, studying the opportunities to determine bio-accumulation of pesticides in terrestrial organisms and interaction of the agro-ecosystem with other ecosystems are relevant as well.

According to the above facts, we can recommend that toxicological and hygienic research should be done to establish of hygienic regulations and standards of pesticide content in the objects of external environment - air of the work area, atmospheric air, the soil, water reservoirs, and foodstuff [7].

\section{REFERENCES}

1.Zakharenko V.A. Bor'ba s sornyakami [Weed control]. Moscow: ZiKR. 2004. 88 (In Russian).

2. Bicki T.J., Felsot A.S. Remediation of pesticide contaminated soil at agrichemical facilities. In Mechanisms of Pesticide Movement into Ground Wate (Honeycutt, R. C. and D. J. Schabacker, Editors). Lewis Publishers, Boca Raton, FL. 1994. 81-99 (In English).

3. Migratsiya zagryaznyayushchikh veshchestv v pochvakh i sopredel'nykh sredakh [Migration of soil and adjacent environment pollutant]. Edited by V.A. Borzilov and S.G. Malakhov. Leningrad: Gidrometeoizdat. 365 (In Russian).

4. Kovda V.A. Changing trends in the biosphere and in biogeochemical cycles. Environmental Conservation. 1976. Vol. 3. Issue 3. 161-170 (In English).

Конфликт интересов. Авторы заявляют об отсутствии конфликта интересов.
5. Matveeva R.A. Ekologicheskaya otsenka migratsii pestitsidov v prirodnykh sredakh [Ecological assessment of migration of pesticides in environments]. Moscow: Kolos. 1982. 126 (In Russian).

6. Shil'nikovaN.V., Andriyashina T.V. Vliyanie pestitsidov na biotsenoz pochvennogo pokrova [Influence of pesticides on the biocoenosis of the soil cover]. Vestnik tekhnologicheskogo universiteta. 2012. Vol. 15. Issue 7. 140-145 (In Russian).

7. Tokhetova L.A., Bekova M.K., Demesinova A.A., Erzhanova E.A. Kompleksnaya otsenka sortoobraztsov yachmenya na ustoychivost' k stressovym faktoram Priaral'ya [Complex assessment of barley cultivars on resistance to stress factors of the Aral Sea region]. Molodoy uchenyy. 2015. N19(99). 11-13 (In Russian).

Conflict of interest. The authors declare no conflict of interest.

Статья поступила в редакцию 03.06.2019

The paper was submitted

to the Editorial Office on 03.06.2019

Статья принята к публикации 25.06.2019

The paper was accepted for publication on 25.06.2019 